\title{
PERILAKU PETANI DALAM PEMAKAIAN PUPUK ANORGANIK UNTUK PERTANIAN DI NAGARI SALIMPAUNG KABUPATEN TANAH DATAR
}

\author{
Emil Liza Marzena ${ }^{1}$ Dedi Hermon² RatnaWilis ${ }^{2}$ \\ Program Studi Pendidikan Geografi \\ Jurusan Geografi \\ Fakultas Ilmu Sosial \\ Universitas Negeri Padang \\ Email:emillizamarzena4@gmail.com
}

\begin{abstract}
ABSTRAK
Penelitian ini bertujuan untuk mengetahui pengetahuan petani tentang pupuk anorganik, perilaku petani dalam pemakaian pupuk anorganik dan faktor yang mempengaruhi perilaku petani. Jenis penelitian yang digunakan adalah deskriptif kualitatif. Teknik pengumpulan data yang digunakan adalah observasi, wawancara dan dokumentasi. Teknik analisis datanya yaitu reduksi data, penyajian data dan verifikasi data. Penelitian ini menghasilkan bahwa : (1) Pengetahuan petani dalam pemakaian pupuk anorganik masih rendah (2) Perilaku petani dalam memakai pupuk anorganik belum berwawasan lingkungan, hal ini dibuktikan dengan sikap petani yang hanya fokus terhadap hasil panen, pemikiran yang instan dan tidak mau mengambil resiko yang dapat merugikan mereka tanpa tahu dampak terhadap lingkungan (3) Faktor yang mempengaruhi perilaku petani tersebut yaitu faktor kebudayaan, faktor pribadi, dan faktor psikologi.
\end{abstract}

Kata Kunci : Perilaku Petani, Pupuk Anorganik

\section{ABSTRACT}

This study aims to determine the knowledge of farmers about inorganic fertilizers, the behavior of farmers in using of inorganic fertilizers and factors that influence the behavior of farmers. The type of study used is qualitative descriptive. Data collection techniques used on this research are observation, interviews and documentation. Data analysis techniques are data reduction, data presentation and data verification. This result of study is: (1) the knowledge of farmers in using of inorganic fertilizers is still low. (2) The behavior of farmers in using inorganic fertilizers is not environmentally sound, it is evidenced by the attitude of farmers who only focus on yields, instant thinking and do not want to take risks that can harm them without knowing the impact on the environment. (3) Factors that influence farmers' behavior are cultural factors, personal factors, and psychological factors.

Keyword: Farmer Behavior, Inorganic Fertilizer

\footnotetext{
${ }^{1}$ Mahassiwa Program Studi Pendidikan Geografi FIS UNP

2 Dosen Jurusan Geografi FIS UNP
} 


\section{PENDAHULUAN}

Pertanian modern (revolusi hijau) telah membawa kemajuan pesat bagi pembangunan pertanian dan masyarakat program pembangunan pertanian selama lebih dari 40 tahun ini berhasil meningkatkan produksi, pendapatan dan kesejahteraan petani. Tetapi pada kenyataannya terungkap bahwa sistem pertanian modern telah membawa banyak konsekuensi yang mengancam lingkungan, penggunaan pupuk kimia berlebih serta praktek pertanian modern lainnya yang dilakukan tidak bijak (Tandisau dan Herniwati, 2009)

Hampir semua aktivitas mengenai pertanian atau perkebunan menggunakan berbagai jenis pupuk. Meski ditujukan untuk memberikan keuntungan bagi manusia, namun dampak dari kegiatan pemupukan perlu diperhatikan, khususnya pada penggunaan pupuk kimia. Aplikasi pemakaian pupuk anorganik secara langsung di lapangan biasanya akan terbentur oleh aspek pengamanan dalam penggunaannya, di mana aspek ini diantaranya sangat ditentukan oleh pengetahuan, sikap dan tindakan petani.

Pengetahuan petani dalam pemakaiaan pupuk sangat membantu dan menunjang kemampuan untuk mengadopsi teknologi dalam usaha taninya (Soehardjo dan Patong, 1973). Sebagai asumsi bahwa semakin tinggi tingkat pendidikan yang ditamatkan maka pola pikir petani juga akan semakin luas. Sehingga rendahnya tingkat pendidikan seorang petani merupakan salah satu faktor penghambat dalam pengembangan sektor pertanian. Dengan begitu tinggi rendahnya tingkat pengetahuan petani juga dapat mendukung dalam upaya pengelolaan lahan pertanian yang tidak merusak ekosistem di sekitarnya.

Pengetahuan adalah hasil dari "tahu" dan ini terjadi setelah orang melakukan penginderaan terhadap suatu objek tertentu. Sebagian besar pengetahuan manusia diperoleh melalui mata dan telinga. Pengetahuan atau kognitif merupakan domain yang sangat penting dalam membentuk tindakan seseorang (Notoatmodjo, 2007).

Pengukuran pengetahuan dapat dilakukan dengan memberikan seperangkat alat tes/kuisioner tentang objek pengetahuan yang mau diukur. Penilaian dilakukan dengan cara membandingkan jumlah jawaban yang benar dengan pertanyaan yang diajukan.

Perilaku petani dicerminkan dalam tindakan sehari-hari baik dalam lingkungan seperti keluarga, masyarakat, maupun lingkungan pekerjaan. Tindakan yang dilakukan secara berulang-ulang dan mendarah daging disebut dengan perilaku. Kebiasaan ini akan berlangsung terus menerus. Perilaku ini juga dapat mempengaruhi cara berfikir petani dalam pengelolaan yang dilakukan untuk memenuhi kebutuhan sehari-hari. (Sutanto, 2002) 


\section{Jenis perilaku petani}

1) Perilaku petani berwawasan lingkungan

Perilaku petani yang diamati adalah bagaimana petani mengola lahan pertaniannya yang berwawasan lingkungan. Selain memiliki hasil panen yang berkualitas baik dan melimpah, petani juga memperhatikan kondisi lahan pertaniannya seperti kondisi tanah, ketersediaan air, penggunaan jumlah pestisida, dan terutama penggunaan pupuk. Penggunaan pupuk yang berimbang yaitu penggunaan pupuk anorganik sesuai dengan dosis dan kebutuhan.

Perilaku petani yang berwawasan lingkungan dalam mengelola lahan pertanian adalah aktivitas petani dalam pemanfaatan sumberdaya yang dapat diperbaharui (renewableresources) dan sumberdaya tidak dapat diperbaharui (unrenewable resources) dengan menekan dampak negatif terhadap lingkungan seminimal mungkin (Mulyadi, 2010).

2) Perilaku petani tidak berwawasan lingkungan

Perilaku petani yang mengeksploitasi lahan yang dilakukan dari hari ke hari secara berlebih dalam upaya untuk meningkatkan kesejahteraan. Tanpa menyadari bahwa bumi bukan milik generasi sekarang saja, tapi juga generasi berikutnya. Rukka (2003) mengungkapkan bahwa petani pertanian anorganik ialah petani yang dalam upaya bercocok tanam padi sawahnya dilakukan dengan cara menggunakan bahan-bahan kimia atau pestisida kimia pada lahannya. Petani hanya fokus terhadap meningkatkan hasil panen dan meningkatnya kesejahteraan, menggunakan pupuk tanpa memperhatikan dampak negatifnya, atau menggunakan pupuk anorganik tidak sesuai dosis atau kebutuhan tanaman.

Faktor yang Mempengaruhi Perilaku Petani

Menurut Setiadi (2003) faktorfaktor yang mempengaruhi perilaku adalah sebagai berikut:

1) Faktor kebudayaan

Budaya adalah penentu keinginan dan perilaku yang paling besar. Di dalamnya: Tempat tinggal, kebiasaan, dan kepercayaan

2) Faktor sosial

Perilaku juga dipengaruhi oleh faktor sosial seperti kelompok kecil, keluarga, dan status sosial

3) Faktor pribadi

Mencakup usia, pengetahuan, tahap daur hidup, pekerjaan, keadaan ekonomi, gaya hidup dan kepribdian atau konsep hidup.

4) Faktor psikologi

Yang mencakup faktor psikologi yaitu motivasi, kesadaran pada lingkungan dan pembelajaran dan juga pengalaman petani

Pemakaian pupuk kimia yang tidak terkendali ini akan berisiko menyebabkan terjadinya pencemaran 
lingkungan pertanian. Karena hal ini dipengaruhi oleh perilaku petani dalam menggunakan dan penanganan pupuk kimia yang belum arif dan belum ramah lingkungan.

Menarik untuk dijadikan sebuah kajian ilmiah, berdasarkan uraian diatas maka penulis tertarik untuk meneliti dan mengambil judul penelitian tentang "Perilaku Petani dalam Pemakaian Pupuk Anorganik untuk Pertanian di Nagari Salimpaung Kabupaten Tanah Datar"

\section{METODOLOGI PENELITIAN}

Dalam melakukan penelitian ini menggunakan metode dan rancangan penelitian yang sesuai dengan tujuan yang ingin dicapai. Berdasarkan rumusan masalah tujuan yang ingin dicapai, maka penelitian ini bersifat deskriptif kualitatif. Menurut Nana Syaodih Sukmadinata (2011: 73), penelitian deskriptif kualitatif diajukan untuk mendeskripsikan dan menggambarkan fenomena-fenomena yang ada, baik bersifat alamiah maupun rekayasa manusia, yang lebih memperhatikan mengenai karakteristik, kualitas, keterkaitan antar kegiatan.

Sebagaimana dituangkan dalam judul penelitian ini, maka yang dijadikan daerah penelitian ini adalah Nagari Salimpaung, Kecamatan Salimpaung, Kabupaten Tanah Datar. Penelitian ini dilaksanakan pada semester ganjil tahun ajaran 2017/2018. Penelitian ini dimulai pada tanggal 17 Desember 2017 sampai dengan tanggal 17 Januari 2018.

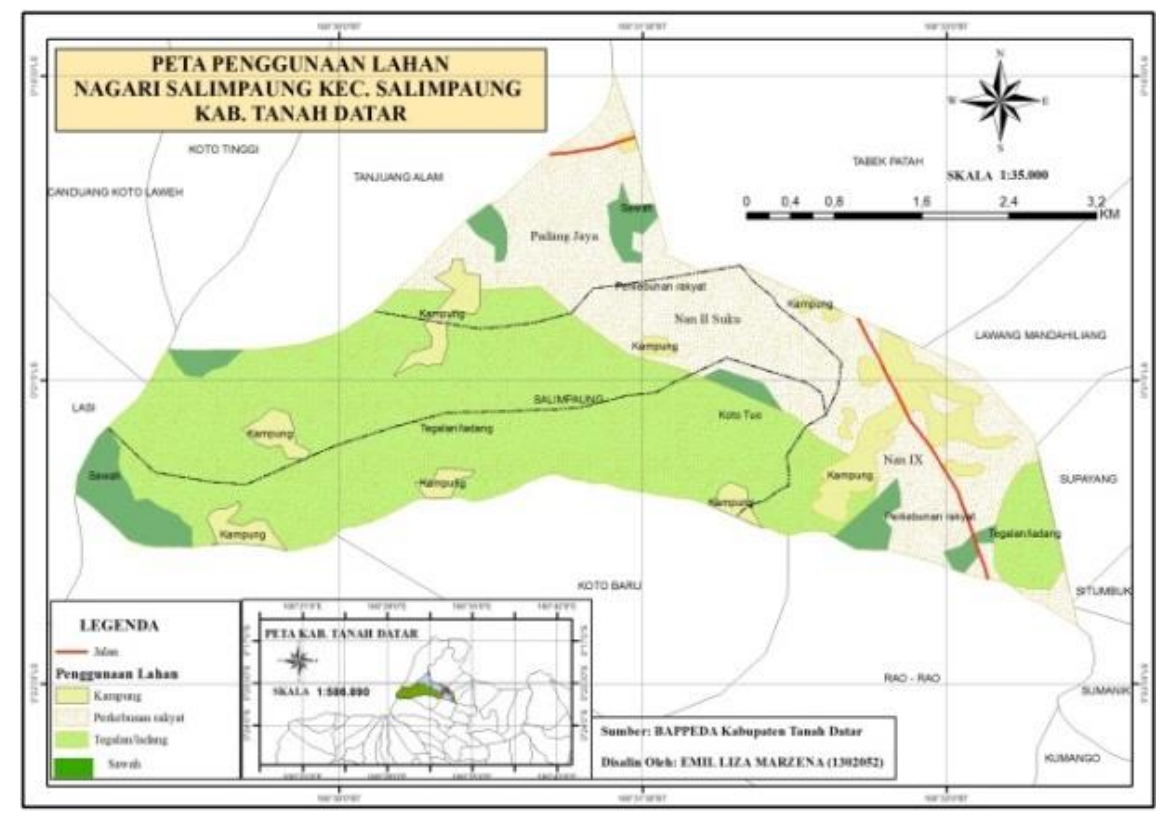

Gambar 1. Peta Penggunaan Lahan 
Dalam penelitian ini informan peneliti dengan teknik purposive sampling, yaitu pengambilan informan secara tidak acak, tetapi dengan pertimbangan dan kriteria tertentu.Informan dalam penelitian ini adalah petani yang menggunakan pupuk anorganik di Nagari Salimpaung dan rata-rata mempunyai lahan sawah terbanyak di Nagari Salimpaung Kabupaten Tanah Datar, kemudian Wali Nagari Salimpaung dan Badan Penyuluhan pertanian Kecamatan (BPK).

Jumlah informan yaitu sebanyak 20 orang, karena rata-rata jawaban yang diberikan sama dan peneliti menghentikan penambahan sampel. Kemudian yang menjadi kunci dari subjek penelitian ini yaitu informan petani di Nagari Salimpaung serta Wali Nagari dan Badan Penyuluhan pertanian Kecamatan (BPK)

Data yang diperoleh Data Primer adalah data yang diperoleh langsung dari sumber atau informan. Data primer dikumpulkan melalui wawancara terstruktur secara langsung dengan menggunakan panduan kuisioner dan kamera. Yang menjadi sumber data primer yaitu petani anorganik yang memiliki rata-rata luas sawah yang banyak di Nagari Salimpaung. Data skunder adalahdata yang sudah ada atau diperoleh melalui studi pustaka yaitu dari buku-buku, koran, majalah, data statistik, jurnal, internet dan lain-lain yang terkait dengan penelitian dan data skunder juga dihimpun dari BPK (Badan Penyuluhan Kecamatan), Dinas Pertanian Kabupaten Tanah Datar dan lembagalembaga terkait dengan penelitian ini. Pengambilan data yang relevan dilakukan dengan menggunakan teknik pengumpulan data informasi dengan cara observasi, wawancara, dan dokumentasi. Selanjutnya Tringulasi dilakukan menurut Wali Nagari, dan Badan Penyuluhan Pertanian Kecamatan (BPK) Salimpaung.

\section{HASIL DAN PEMBAHASAN}

Hasil wawancara dan pengamatan yang peneliti lakukan di Nagari Salimpaung diperoleh informasi bahwa pengetahuan petani tentang pemakaian pupuk anorganik dapat disimpulkan bahwa pengetahuan petani tentang pupuk anorganik masih rendah, petani hanya sekedar tahu pupuk anorganik yaitu pupuk yang dibuat dan dijual-belikan di tempat penjual pupuk. Namun petani di Nagari Salimpaung masih banyak yang belum mengetahui dampak positif dan negatif apa saja yang akan disebabkan oleh pemakaian pupuk anorganik secara terus menerus terhadap tanah maupun lingkungan.

Perilaku petani dalam pemakaian pupuk anorganik dapat disimpulkan bahwa perilaku petani dalam memakai pupuk anorganik belum semuanya berwawasan lingkungan, karena petani hanya fokus terhadap hasil panennya saja, Takaran 
pemakaiannya banyak yang mengulangi takaran itu-itu saja sehingga tidak ada peningkatan atau penurunan hasil panen yang melesat karena petani di Nagari Salimpaung ini masih bersifat instan dan tidak mau mengambil resiko yang dapat merugikan mereka.

Adapun faktor-faktor yang mempengaruhi perilaku petani adalah Faktor yang mempengaruhi perilaku petani dalam pemakaian pupuk anorganik di Nagari Salimpaung yaitu Faktor kebudayaan yang meliputi kebiasaan, dan kepercayaan, kemudian faktor pribadi yang mencakup usia dan pengetahuan, dan faktor psikologi yang mencakup kesadaran pada lingkungan, pembelajaran dan juga pengalaman petani.

\section{PEMBAHASAN}

Berdasarkan hasil penelitian yang telah ditemui peneliti saat di lapangan melalui Observasi, Wawancara, dan Dokumentasi maka diperoleh hasil penelitian sebagai berikut:

Pertama, pengetahuan petani masih rendah, petani hanya sekedar tahu pupuk anorganik yaitu pupuk yang dibuat dan dijual-belikan di tempat penjual pupuk. Namun petani di Nagari Salimpaung masih banyak yang belum mengetahui dampak negatif apa saja yang akan disebabkan oleh pemakaian pupuk anorganik secara terus menerus terhadap tanah maupun lingkungan.

Dari segi dampak positif dan negatif pemakaian pupuk anorganik tersebut yang petani ketahui tentang dampak positif pemakaian pupuk anorganik yaitu dapat meningkatkan hasil panen, sedangkan negatifnya tanah mengeras. Dan berdasarkan hasil penelitian, jenis pupuk anorganik yang petani ketahui yaitu jenis pupuk anorganik yang biasa digunakannya seperti NPK, ZA, POSCA dan UREA. Alasannya yaitu karna biasa menggunakan pupuk tersebut dan rangsanganya terhadap hasil panen lebih cepat.

Pengetahuan petani sangat membantu dan menunjang kemampuan untuk mengadopsi teknologi dalam usaha taninya (Soehardjo dan Patong, 1973). Sebagai asumsi bahwa semakin tinggi tingkat pendidikan yang ditamatkan maka pola pikir petani juga akan semakin luas. Sehingga rendahnya tingkat pendidikan seorang petani merupakan salah satu faktor penghambat dalam pengembangan sektor pertanian. Dengan tingginya tingkat pengetahuan petani juga dapat mendukung dalam upaya pengelolaan lahan pertanian yang tidak merusak ekosistem di sekitarnya.

Pengukuran pengetahuan dapat dilakukan dengan memberikan seperangkat alat tes/kuisioner tentang objek pengetahuan yang mau diukur. Penilaian dilakukan dengan cara membandingkan jumlah jawaban yang benar dengan pertanyaan yang diajukan.

Kedua, perilaku petani dalam memakai pupuk anorganik di Nagari 
Salimpaung Kabupaten Tanah Datar belum semuanya berwawasan lingkungan, karena petani hanya fokus terhadap hasil panennya saja, takaran pemakaiannya banyak yang mengulangi takaran itu-itu saja sehingga tidak ada peningkatan atau penurunan hasil panen yang melesat karena petani di Nagari Salimpaung ini masih bersifat instan dan tidak mau menambil resiko yang dapat merugikan mereka. Sekalipun ada yang mengikuti anjuran orang penyuluh tetapi jika hasilnya tidak memuaskan bagi mereka, maka petani di Nagari Salimpaung akan mempercayai apa yang sudah dipercayai sebelumnya dan mengikuti cara pemakaian yang dilakukan sebelumnya. Dan petani di Nagari Salimpaung lebih memperhatikan hasil panen ketimbang pengaruh terhadap lingkungannya dalam pemakaian pupuk anorganik.

Hal ini sesuai dengan perilaku petani dicerminkan dalam tindakan sehari-hari baik dalam lingkungan seperti keluarga, masyarakat, maupun lingkungan pekerjaan. Tindakan yang dilakukan secara berulang-ulang dan mendarah daging disebut dengan perilaku. Kebiasaan ini akan berlangsung terus menerus. Perilaku ini juga dapat mempengaruhi cara berfikir petani dalam pengelolaan yang dilakukan untuk memenuhi kebutuhan sehari-hari. Oleh sebab itu timbul suatu dorongan atau semacam motivasi yang ada dalam diri mereka. Cara berfikir petani diturunkan dari generasi tua ke generasi muda dalam perjalanan sosialisasi primer. Dengan demikian, tercipta model perilaku yang berorientasi pada sistem nilai dan diikuti dengan patuh untuk jangka waktu yang lama, meskipun situasi yang menjadi dasarnya sudah lama berubah (Soekanto, 1983).

Adapun jenis perilakunya yaitu : Perilaku petani yang mengeksploitasi lahan yang dilakukan dari hari ke hari secara berlebih dalam upaya meningkatkan kesejahteraan. Tanpa menyadari bahwa bumi bukan milik generasi sekarang saja, tapi juga generasi berikutnya. Rukka (2003) mengungkapkan bahwa petani pertanian anorganik ialah petani yang dalam upaya bercocok tanam padi sawahnya dilakukan dengan cara menggunakan bahan-bahan kimia atau pestisida kimia pada lahannya. Petani hanya fokus terhadap meningkatkan hasil panen dan meningkatnya kesejahteraan, menggunakan pupuk tanpa memperhatikan dampak negatifnya, atau menggunakan pupuk anorganik tidak sesuai dosis atau kebutuhan tanaman.

Ketiga, faktor yang mempengaruhi perilaku petani dalam pemakaian pupuk anorganik di Nagari Salimpaung Kabupaten Tanah Datar yaitu faktor kebudayaan yang meliputi kebiasaan, dan kepercayaan, kemudian faktor pribadi yang mencakup usia dan pengetahuan, dan faktor psikologi yang mencakup kesadaran pada lingkungan, 
pembelajaran dan juga pengalaman petani.

Petani yang memiliki usia yang lebih tua cenderung berfikir instan tanpa memikirkan dampak negatif yang akan diakibatkan dari pemakaian pupuk anorganik untuk kedepannya. Selain itu pengalaman bertani mempengaruhi cara petani dalam bertani, karena selama bertani petani sudah mendapatkan banyak pengalaman dan pengetahuan yang nantinya akan mempengaruhi apa yang sudah lama mereka percayai dan apa yang sudah lama diyakininya contohnya dalam takaran pemakaian pupuk dan cara bercocok tanam mereka yang sudah lama bertani akan lebih memilih pemakaian yang dilakukan sebelumnya.

Pengetahuan atau pendidikan juga menjadi faktor utama yang mempengaruhi perilaku petani dalam menggunakan pupuk, petani yang memiliki pengetahuan lebih tinggi akan lebih mempertimbangkan pemakaian pupuk yang berimbang yang disampaikan oleh penyuluh, memperhatikan dampak yang akan disebabkan dan lebih mengetahui dan paham soal pemupukan khususnya, dan melakukan perubahan yang akan berdampak positif bagi diri dan lingkungannya. Sedangkan kurangnya pengetahuan dan pendidikan bagi petani akanmempengaruhi pola pikir dan perilakunya dalam bertani. Mereka hanya mengikuti dan mempercayai hal yang di yakini dan tentunya tidak merugikan bagi mereka.

Terakhir kepercayaan dan kebiasaan petani dalam bertani mempengaruhi perilaku karena hal itu sudah menjadi hal yang sehari-hari dilakukannya dan mendarah daging sehingga susah untuk diubah.

Menurut Setiadi (2003) Hal ini sesuai dengan faktor-faktor yang mempengaruhi terbentuknya perilaku petani dalam pemakaian pupuk anorganik dapat dikelompokkan menjadi empat jenis, yaitu:

1) Faktor kebudayaan Budaya adalah penentu keinginan dan perilaku yang paling besar. Di dalamnya: Tempat tinggal, kebiasaan, dan kepercayaan

2) Faktor sosial

Perilaku juga di pengaruhi oleh faktor sosial seperti kelompok kecil, keluarga, dan status sosial

3) Faktor pribadi Mencakup usia, pendidikan, tahap daur hidup, pekerjaan, keadaan ekonomi, gaya hidup dan kepribadian atau konsep hidup.

4) Faktor psikologi

Yang mencakup faktot psikologi yaitu motivasi, kesadaran pada lingkungan dan pembelajaran dan juga pengalaman petani

\section{PENUTUP}

\section{Kesimpulan}

Pengetahuan petani tentang pupuk anorganik masih rendah, petani 
hanya sekedar tau pupuk anorganik yaitu pupuk yang dibuat dan dijualbelikan di tempat penjual pupuk. Sehingga berpengaruh terhadap perilaku petani. belum semuanya berwawasan lingkungan, karena petani hanya fokus terhadap hasil panennya saja, takaran pemakaiannya banyak yang mengulangi takaran itu-itu saja sehingga tidak ada peningkatan atau penurunan hasil panen yang melesat karena petani di Nagari Salimpaung ini masih bersifat instan dan tidak mau menambil resiko yang dapat merugikan mereka.

Adapun Faktor yang mempengaruhi perilaku petani dalam pemakaian pupuk anorganik di Nagari Salimpaung Kabupaten Tanah Datar yaitu Faktor kebudayaan yang meliputi kebiasaan, dan kepercayaan, kemudian faktor pribadi yang mencakup usia dan pengetahuan, dan faktor psikologi yang mencakup kesadaran pada lingkungan, pembelajaran dan juga pengalaman petani.

\section{Saran}

1. Bagi petani disarankan agar selalu bisa selektif dalam pemilihan pupuk sehingga tidak merusak lingkungan. Mengikuti penyuluhan yang dilakukan oleh pemerintah setempat guna untuk keberlangsungan berbudidaya dan bertani. Kemudian lebih berfikir bijak dalam pemakaian pupuk untuk pertanian di Nagari Salimpaung
2. Bagi BPK agar disarankan lebih meluaskan lagi daerah untuk penyuluhan untuk melakukan atau memberikan pengarahan yang mudah dan dapat dipahami petani dalam penggunaan pupuk

3. Bagi wali nagari selalu mengarahkan dan memberikan fasilitas yang bisa digunakan masyarakat petani untuk menggunakan pupuk. Kemudian lebih memperhatikan kinerja dari penyuluhan sehingga lebih ditingkatkan lagi.

\section{DAFTAR PUSTAKA}

Herniwati, P. T. (2009). Prospek Pengembangan Pertanian

Organik. Jurnal. Balai Teknologi Pertanian Sulawesi Selatan

Mulyadi. (2010). Pengaruh Kearifan Lokal, Locus of Control, Dan Motivasi Terhadap Perilaku Berwawasan Lingkungan Petani Dalam Mengelola Lahan Pertanian Di Kabupaten Soppeng. Skripsi. Jurusan Teknik Sipil Dan Perencanaan Universitas Negeri Makasar. Makasar.

Notoatmodjo, S. 2007. Promosi

Kesehatan dan Ilmu Perilaku.

Jakarta: Rineka Cipta.

Rukka, H. 2003. Motivasi Petani dalam

Menerapkan Usahatani Organik

Padi Sawah. Tesis: Sekolah 


\section{Tinngi Pasca Sarjana IPB}

\section{Bogor.}

Setiadi, Nugroho J. 2003. Prilaku

Konsumen. Jakarta: Prenada Media

Soeharjo, A \& Patong. 1973. Sendisendi Pokok Usaha Tani. Jurusan ilmu-ilmu sosial ekonomi pertanian. Fakultas Pertanian. Bogor: IPB

Sukmadinata, Nana Syaodih. 2011. Metode Penelitian Pendidikan.

Bandung: PT Remana

Rosdakarya

Sutanto, R. 2002. Pertanian Organik : Menuju Pertanian Alternatif dan Berkelanjutan.Yogyakarta :

Kanisius 